\title{
Homologous Protein
}

National Cancer Institute

\section{Source}

National Cancer Institute. Homologous Protein. NCI Thesaurus. Code C40992.

A protein similar in structure and evolutionary orig in to a protein in another species. 